\title{
Fritzolenellus lapworthi (Peach and Horne, 1892) from the lower Cambrian (Cambrian Series 2) Bastion Formation of North-East Greenland
}

\author{
MARTIN STEIN
}

\begin{abstract}
Stein, M. 2008-01-03. Fritzolenellus lapworthi (Peach and Horne, 1892) from the lower Cambrian (Cambrian Series 2) Bastion Formation of North-East Greenland ( 2008 by Bulletin of the Geologi-cal Society of Denmark, Vol. 56, pp. 1-10. ISSN 0011-6297. (www.2dgf.dk/ publikationer/bulletin) https://doi.org/10.37570/bgsd-2008-56-01

Fossil collections from the lower Cambrian (Cambrian Series 2) Bastion Formation at Albert Heim Bjerge in North-East Greenland acquired during 1950 and 1951 contain some 60 specimens of olenellid trilobites. Although morphologically variable, the material can be attributed to a single species, Fritzolenellus lapworthi (Peach and Horne, 1892), previously known from the 'Fucoid' Beds of north-west Scotland. Immature specimens allow a first, limited, description of the ontogeny of Fritzolenellus. The presence of $F$. lapworthi in North-East Greenland offers an important tie point for correlation of Olenellus-bearing strata (Cambrian Series 2, Stage 4) across eastern Laurentia.
\end{abstract}

Keywords: Fritzolenellus lapworthi, Trilobita, Cambrian Series 2, Bastion Formation, Greenland

Martin Stein, [martin.stein@geo.uu.se] Uppsala University, Department of Earth Sciences, Palaeobiology program, Villavägen 16, SE-752 36 Uppsala,Sweden

In 1932, Christian Poulsen described lower Cambrian faunas from collections from Andrée Land and Ella $\varnothing$, acquired during two Danish expeditions to the east coast of Greenland in the late 1920s. The material was derived from two Cambrian formations, the Bastion and the Ella Island formations respectively. While six species of Olenellus Hall, 1861 and Paedeumias Walcott, 1910 were described from the Ella Island Formation, only one indeterminate fragment was recovered from the Bastion Formation (Poulsen, 1932, p. 26, pl. 4, fig. 6). Additional material from three localities, Ella Ø, Sødal/Ole Rømer Land, and Albert Heim Bjerge, was collected during subsequent expeditions to North-East Greenland in the early 1950s. Cowie and Adams (1957) reported occurrences of four species of Olenellus from Albert Heim Bjerge, and two from the other localities, but no taxonomic work on the material was published. The present study attributes the material of Olenellus from the Upper Bastion Formation at Albert Heim Bjerge to Fritzolenellus lapworthi (Peach and Horne, 1892), formerly known only from the An t'Sron Formation of north-west Scotland. F. lapworthi occurs in the 'Fucoid' Beds (Cowie and McNamara, 1978), which constitute the lower part of the formation. The overlying 'Salterella Grit', forming the upper part of the formation, is characterized by an abundance of Salterella, which also occurs rarely in the 'Fucoid' Beds. In North-East Greenland, Salterella occurs in the Bastion Formation (Skovsted 2006) and in the overlying Ella Island (Poulsen, 1932) and Hyolithus Creek Formations (Cowie and Adams, 1957). The small shelly fauna of the Upper Bastion and Ella Island Formations has recently been described by Skovsted (2006), who concluded a probable middle Dyeran age (Cambrian Series 2; Cambrian Stage 4). The occurrence of Fritzolenellus lapworthi in the Upper Bastion Formation may prove to be an important tie-point for correlation of the 'Fucoid' Beds of north-west Scotland with other areas of eastern Laurentia.

\section{Material}

The material comprises 64 specimens and was collected by J.W. Cowie and PJ. Adams in the early 1950s from shales of the Bastion Formation at Albert Heim Bjerge, North-East Greenland $\left(74^{\circ} 4.3^{\prime} \mathrm{N}, 23^{\circ} 20^{\prime} \mathrm{W}\right.$, Fig. 1). The locality is illustrated by Cowie and Adams (1957, fig. 11, pl. 2). Exact stratigraphic levels can no longer be determined. Sample horizons in the 

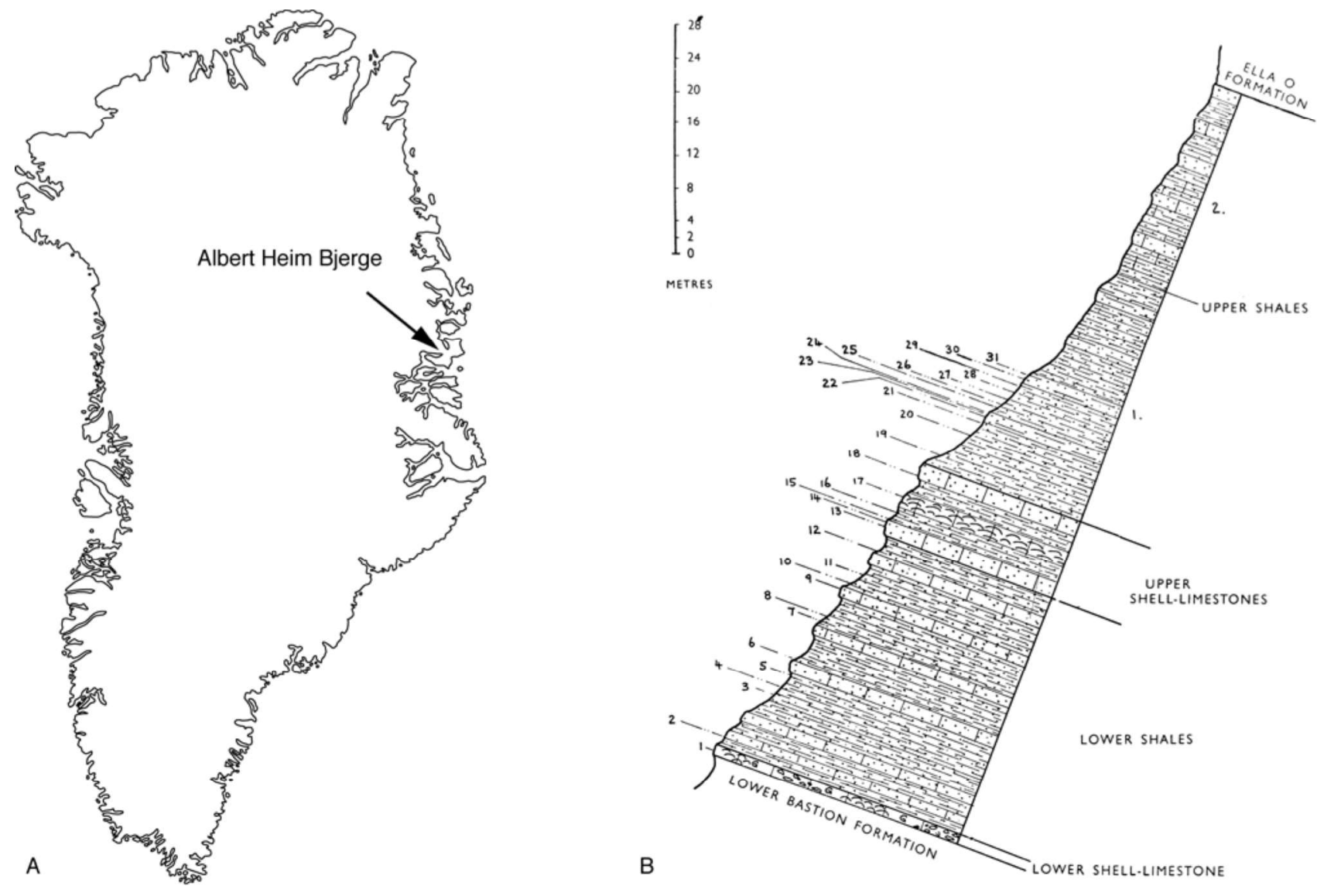

Figure 1. A. Map of Greenland, arrow indicates locality where the material was collected; B. Profile of the Upper Bastion Formation at Albert Heim Bjerge (from Cowie and Adams 1957).

profile are marked on the slabs, or indicated on the labels accompanying the specimens. According to the published profile (Fig. 1B, Cowie and Adams, 1957, fig. 16) and the given sample horizon numbers, the material should be derived from the Lower Shales of the Upper Bastion Formation, but in the text (Cowie and Adams, 1957, p. 56) only an indeterminate olenellid is mentioned, whereas the bulk of the olenellid material is said to occur in the Upper Shales (Cowie and Adams, 1957, p. 58). That material either is not preserved in the collections, or the identification of the sample horizon numbers is wrong.

The entire collection is deposited in the National Museum of Wales, Cardiff, Wales, UK (NMW prefix). Figured specimens are NMW 97.56G.474-475, 531-536, 539-542, 544-554. The collection also houses specimens (NMW 97.56G.555-556) from the Ella Island Formation at Albert Heim Bjerge, which are compared to Olenellus hanseni (Poulsen, 1932).

The type material of Fritzolenellus lapworthi is stored in the collections of the British Geological Survey, Keyworth, Nottingham, UK (GSE prefix).

\section{Systematic paleontology}

Genus Fritzolenellus Lieberman, 1998

Type species. Olenellus truemani Walcott, 1913

Discussion. The diagnosis for Fritzolenellus provided by Lieberman $(1998,1999)$ was largely based on the type species, F. truemani (Walcott, 1913). The well preserved material of Fritzolenellus lapworthi described herein conflicts with some of the characters given for the genus: due to the greater length of the ocular lobes, the angle between a line from the posterior tip of the ocular lobe to the junction of the posterior margin of the lobe with LA is less than 10 to 15 degrees in F. lapworthi; due to the wide ocular furrow, the transverse profile of the ocular lobe in F. lapworthi can not be described as convex; the width (tr.) of the extraocular area exceeds $75 \%$ of the glabellar width at L1 in both F. truemani and F. lapworthi; the macropleural spine on T3 projects well beyond T15 in $F$. lapworthi; the pleural spines on T6 through T14 are developed as long and broad sweeping projections; 
pleural spines on $\mathrm{T} 4$ and $\mathrm{T} 5$ are shorter, more straight and posterolaterally directed; median nodes are present on all thoracic axial rings in F. lapworthi; in F. lapworthi, the length (exsag.) of the thoracic pleural furrows is greater than the length (exsag.) of the posterior band, as in Olenellus (cf. Lieberman 1999 p. 96).

Fritzolenellus lapworthi (Peach and Horne, 1892)

Figures $3 \mathrm{~A}-8 \mathrm{~A}$

1892 partim Olenellus lapworthi Peach and Horne, pp. 227-242, pl. 5 figs. 2-4, 6 .

1892 ? Olenellus lapworthi Peach and Horne, pl. 5 figs. $7,9,10,12,13$, non 5,11 .

1894 Olenellus lapworthi Peach. Peach, pp. 662-664, pl. 29 fig. 1.

1894 Olenellus lapworthi var. elongatus Peach, p. 664, pl. 29 fig. 4.

1910 Olenellus lapworthi Peach. Walcott, pp. 331-332, pl. 39, figs. 4-?6, non 1-3.

1937 Olenellus lapworthi Peach. Lake, pp. 238-240, pl. 33 , fig. 10, pl. 34, figs. 1, 2, 5, non pl. 33, fig. 11, pl. 34 figs. $3,4,6$.

1937 Wanneria? sp. Lake, pp. 246-247, pl. 35, fig. 5.

1978 Olenellus lapworthi Peach and Horne, 1892. Cowie and McNamara, pp. 620-624, pl. 69 figs 1-6.

1999 Fritzolenellus lapworthi (Peach and Horne, 1892). Lieberman, p.97.

2006 Olenellus cf. roddyi Resser and Howell, 1938. Skovsted, p. 1093, figs. 5.1-3.

Description. Cephalon nearly semicircular in outline, its length (sag.) only slightly exceeding one half of its width (tr.). Width (tr.) of LO slightly greater than that of L1 and L2. L3 reaches almost width (tr.) of LA. SO and S1 bend backward from axial furrow. S2 not isolated from axial furrow, but shallows distally (Figs. 3A, B, D). SO, S1, and S2 do not extend across axis, leaving continuous medial area extending back to median tubercle at posterior edge of LO (Figs. 3A, B). S3 traverses axis. Ocular lobes strongly arched, posterior tips situated slightly posterior to SO. Inner band has more than twice the width of outer band; ocular furrow distinct. Parafrontal band developed (Figs 3A, B, D, 4B), but indistinct adaxially. Interocular area arched dorsally, maximum width (tr.) equals roughly width of ocular lobe. Width (tr.) of extraocular area about one fourth of cephalic width, covered with anastomosing genal caeca radiating from base of ocular lobe. Cephalic border moderately convex, width less than one half length of LO; width increases toward the genal spines. Border carries terrace ridges on exterior slope (Fig. 3D). Cephalic bor-

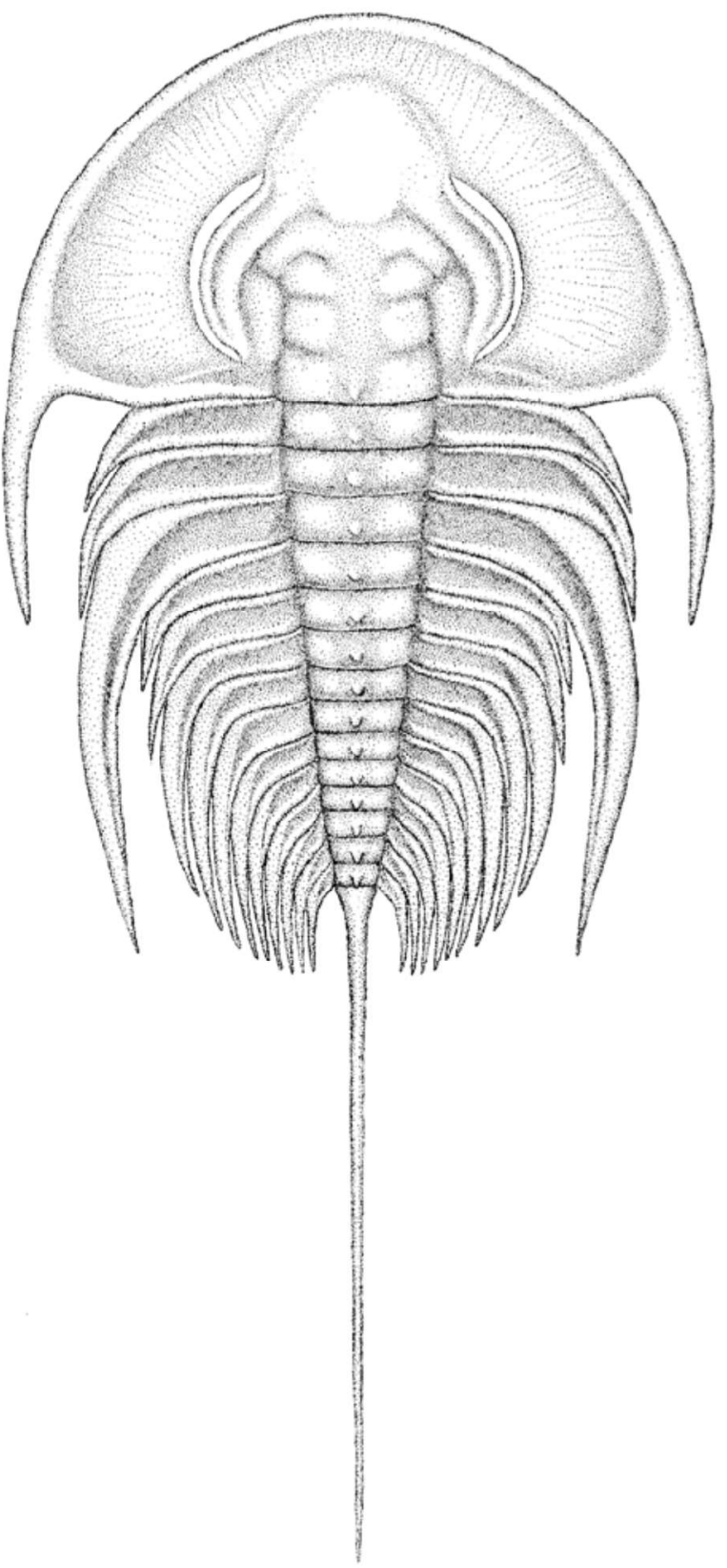

Figure 2. Reconstruction of the mature morphology of Fritzolenellus lapworthi (Peach and Horne, 1892); pygidium and tergites posterior to 15 th thoracic tergite not known.

der furrow is shallow and wide, not sharply defined. Anterior border furrow shallows adaxially, but a plectrum is not developed. Posterior border of nearly equal width to cephalic border in anterior half of cephalon; straight or slightly curving posteriorly to intergenal swellings, gently curving anteriorly distally. Base of the genal spine roughly opposite posterolateral margin of LO. Intergenal spines not present in holaspides. Posterior ocular line indistinct (Fig. $3 \mathrm{~B})$. Doublure ornamented with terrace ridges, as 

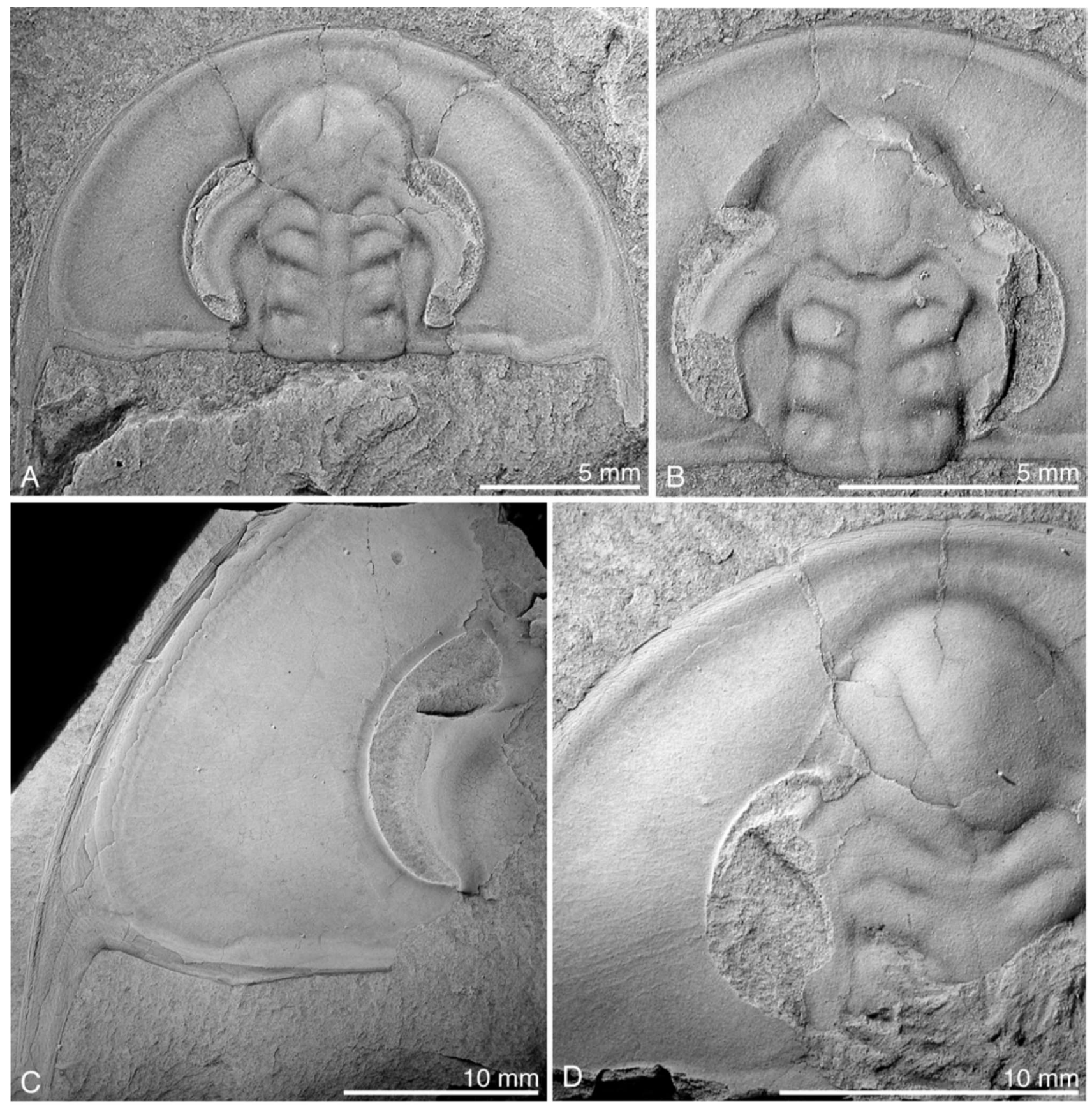

Figure 3. Fritzolenellus lapworthi (Peach and Horne, 1892), cephala. All specimens from the Upper Bastion Formation, Albert Heim Bjerge. A. NMW 97.56G.534; B. NMW 97.56G.535; C. NMW 97.56G.536; D. NMW 97.56G.533.

dorsal surface of genal spine (Fig. 3C). Rostral plate narrow (Fig. 4A-C). Only fragments of the hypostome are preserved (Fig. 5B); these do not allow a proper description. In some specimens a fine reticulate pattern is observed on the surface of glabella, interocular area, and intercalary to the genal caecae on the extraocular area (Fig. 3C).

Only prothorax preserved. T15 carries median spine of length equal to length of prothorax. Spine has broad, spatulate base, usually showing a flexure proximal to this socket (Fig. 5C). Axis tapers evenly to $\mathrm{T} 9$, more rapidly posterior to that (Figs. 4B, 5A). $\mathrm{T} 3$ is macropleural and macrospinous; pleural spine extends backward over whole length of prothorax. Axial furrow shallow and ill-defined opposite pleural furrow, more sharply defined opposite posterior band. Median node present on posterior edge of each axial ring along prothorax, but weak in T1 through T4. Articulating half ring about one third length (sag.) of axial ring. Inner portions of pleural field narrow 

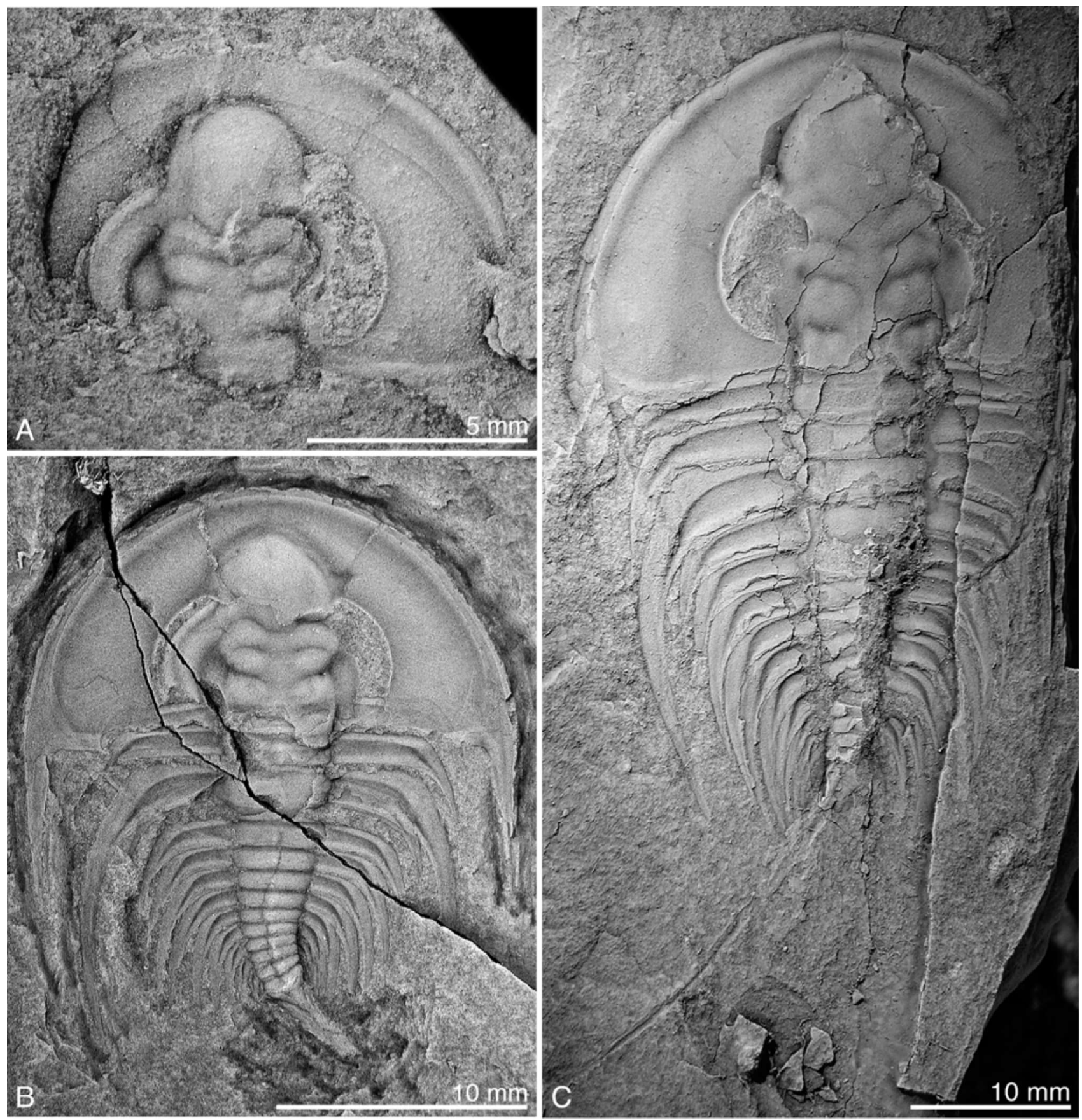

Figure 4. Fritzolenellus lapworthi (Peach and Horne, 1892). All specimens from the Upper Bastion Formation, Albert Heim Bjerge. A. Cephalon with impression of rostral plate (NMW 97.56G.531); B-C. Almost complete specimens, rostral plate swung back under thorax (NMW 97.56G.475, NMW 97.56G.474).

rapidly posterior to $\mathrm{T} 3$, are virtually absent posterior to T12. Pleural furrow gradually more sickle-shaped toward posterior; extends into pleural spines. Pleural spines of T1-T2 and T4-T5 falcate. Pleural spines of T6 through T14 sickle shaped. Spines of T6 through T9 of roughly even length; T10 to T14 successively shorter toward the posterior, terminating in roughly transverse line.
Ontogeny. The specimens in the present material range in total cephalic length from about $1 \mathrm{~mm}$ (Fig. 6A) to more than $25 \mathrm{~mm}$. Specimens with a total cephalic length less than $4 \mathrm{~mm}$ (Figs 6, 7A, B) are characterized by a lesser degree of differentiation of the glabellar lobes and the presence of intergenal spines and represent immature specimens (cf. stages I-IV of Olenellus fowleri Palmer, 1998, Palmer 1957). The 

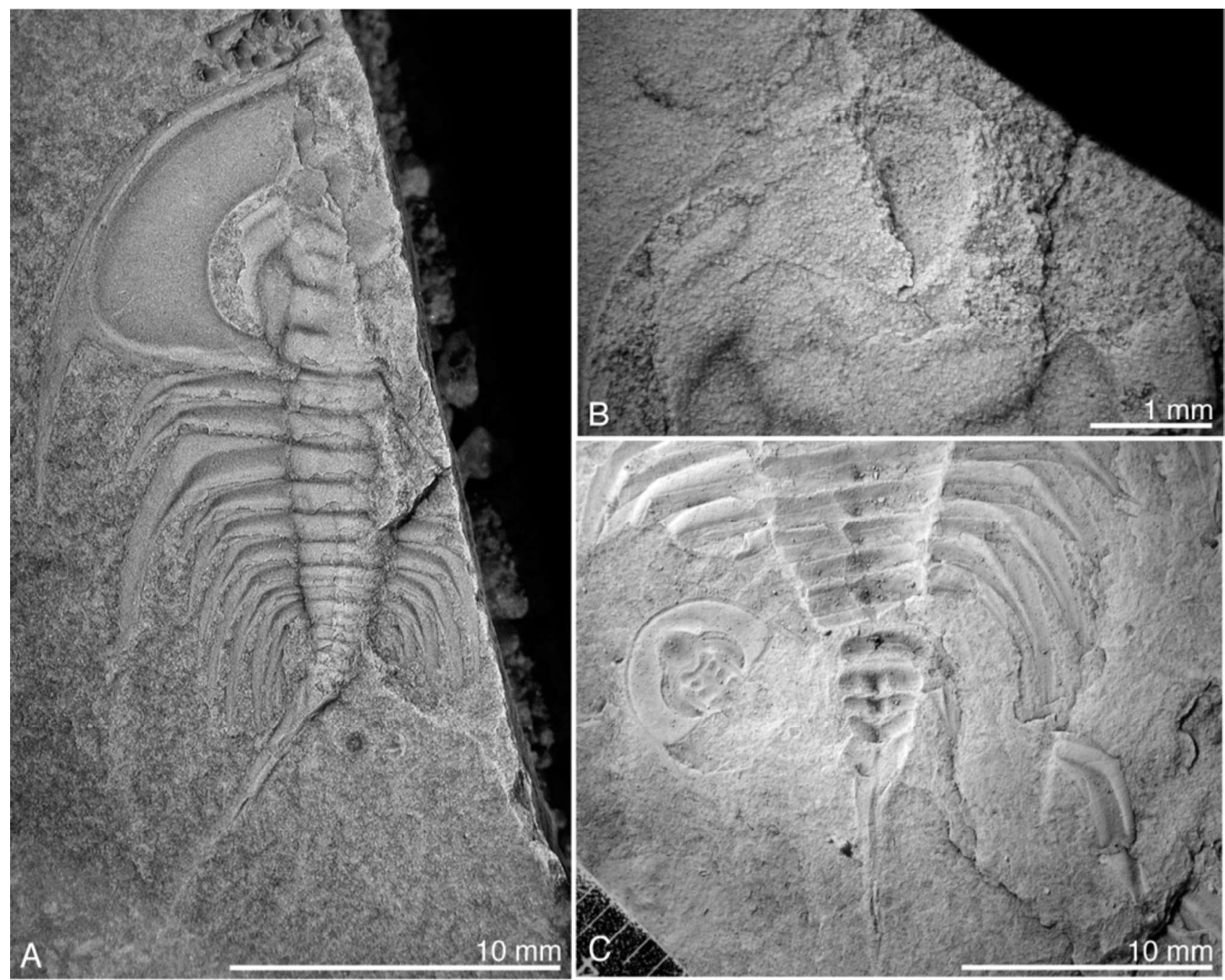

Figure 5. Fritzolenellus lapworthi (Peach and Horne, 1892). All specimens from the Upper Bastion Formation, Albert Heim Bjerge. A. Almost complete specimen (NMW 97.56G.540); B. Part of cephalon showing fragment of hypostome (NMW 97.56G.541); C. Mold of posterior portion of thorax, showing axial nodes (NMW 97.56G.553).

available material is not sufficient in quality or quantity to allow an exhaustive description of the ontogeny and identification of stages but comparisons to developmental stages of Olenellus fowleri as described by Palmer (1957) are made where possible.

The smallest specimens are poorly preserved casts (Figs. 6A-C, D, E). Segmentation in the interocular areas is indicated. The interocular portions opposite L1 extend into the intergenal spines as an intergenal ridge. $\mathrm{LO}$ through $\mathrm{L} 3$ are serially similar. A border appears to be developed (Figs. 6B, E). The ocular lobe is separated from the lateral and posterolateral margins. The developing genal spines appear anterolaterally to the intergenal spine (Fig. 6B arrows), indicating a stage comparable to III a of Olenellus fowleri (Palmer 1957).

In succeeding stages (Fig. 6D), segmentation is no longer expressed in the interocular areas, and LA starts to expand in length (sag.) and constricts L3 adaxially. These cephala seem to represent stages later than stage III c of Olenellus fowleri.

Inlater stages, the genal spine migrates outward and slightly forward, leaving a straight posterolateral margin (Fig. 6G). LA expands further and starts to take on its inflated form (Figs. 6H-K). LO and L1 start to expand, further constricting L2 and L3. The ocular lobes show proximally the beginning differentiation in outer and inner bands (Fig. $6 \mathrm{H}$ ). The preocular furrow starts to develop (Figs. 6D, 7A). Subsequently, the intergenal ridge becomes separated from the interocular area and S3 takes on its characteristic shape (Figs. 7B). 

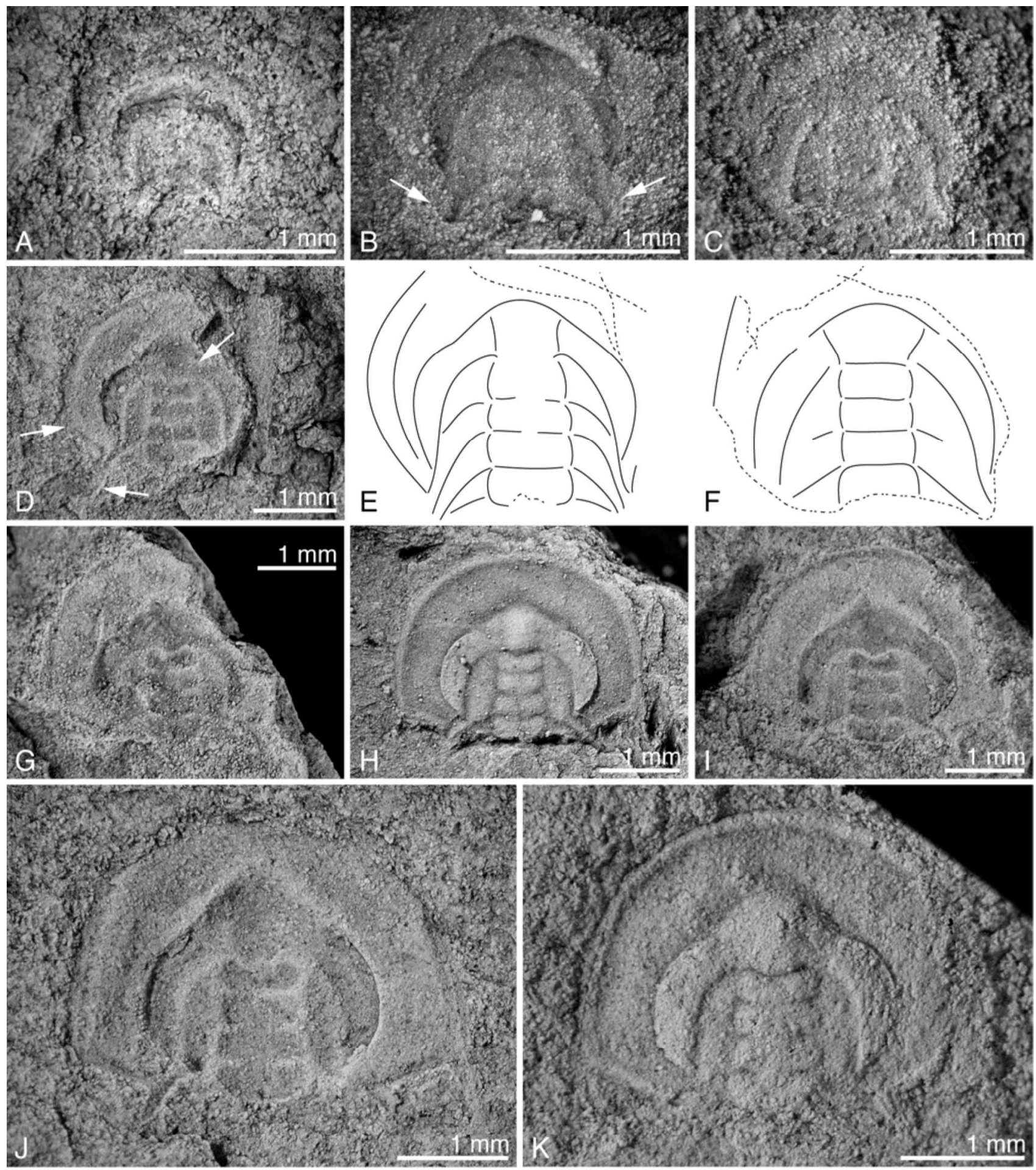

Figure 6. Fritzolenellus lapworthi (Peach and Horne, 1892). All specimens from the Upper Bastion Formation, Albert Heim Bjerge; immature cephala. A. Smallest individual found, mold (NMW 97.56G.550); B. Mold, arrows point to genal spines (NMW 97.56G.547); C. Mold (NMW 97.56G.548); D. Mold, arrows point to proximal depression of ocular furrow, genal spine, intergenal spines (top to bottom) (NMW 97.56G.546); E. Line-drawing of NMW 97.56G.547; F. Line-drawing of NMW 97.56G.548; G. Mold (NMW 97.56G.549); H. Complete cephalon (NMW 97.56G.532); I. Mold (NMW 97.56G.545); J. Mold (NMW 97.56G.542); K. Almost complete cephalon (NMW 97.56G.544). 

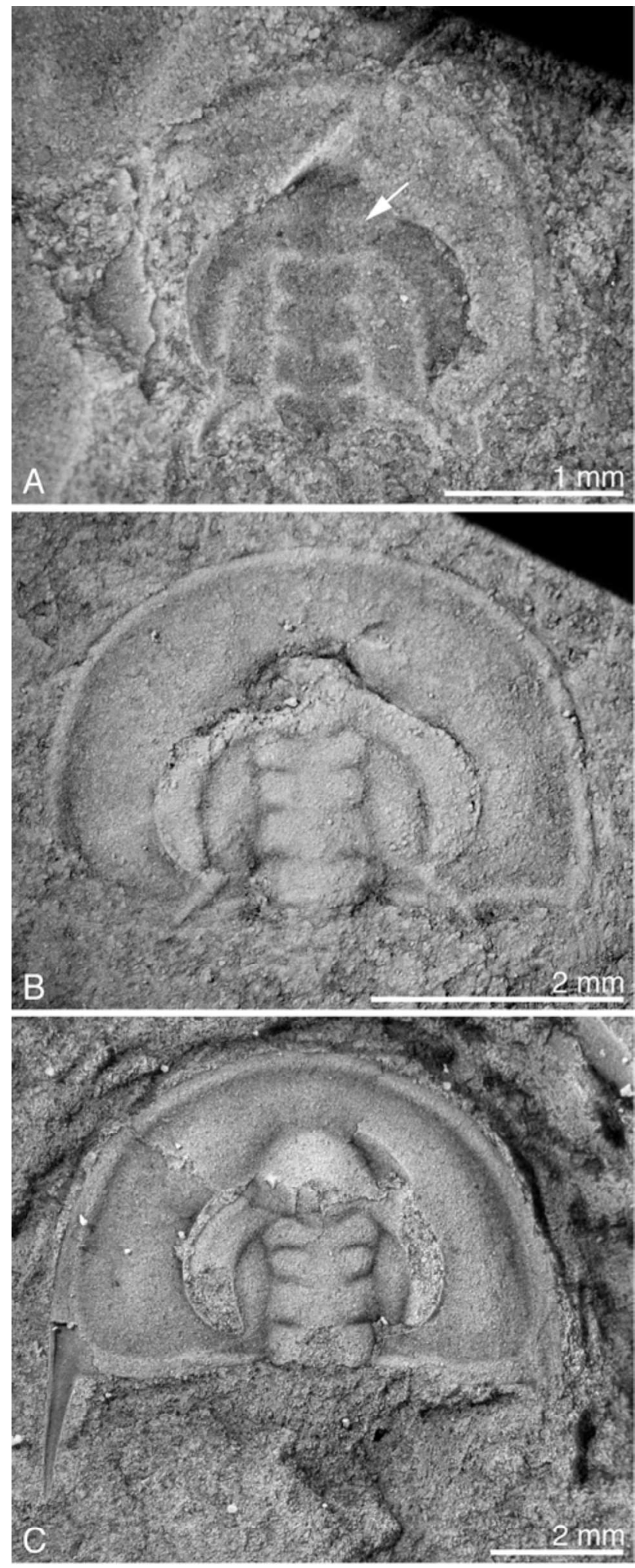

Figure 7. Fritzolenellus lapworthi (Peach and Horne, 1892). All specimens from the Upper Bastion Formation, Albert Heim Bjerge; immature cephala. A. Mold, arrow points to ocular furrow constricting LA in a way resembling lateral glabellar furrows (NMW 97.56G.551); B. Almost complete cephalon, showing intergenal spine separated from the interocular area (NMW 97.56G.554); C. Cephalon showing advanced glabellar differentiation (NMW 97.56G.551).
Variation. Through the description of conspecific fossils from the Pioche Formation, occurring in different modes of preservation (silicified and preserved in shale; Palmer, 1998) it became apparent that a considerable amount of the variation observed in olenelloid trilobites preserved in shale can be attributed to taphonomic deformation (Palmer, 1998). This was studied quantitatively by Webster and Hughes (1999) who demonstrated that compaction-related deformation in olenelloid trilobites results in lateral shifting of morphological landmarks. The material from the Bastion Formation shows distinct signs of deformation, as evident in e.g. slightly asymmetric cephala (Figs. 4C, 7C). In general, there is some variation in the outline of the cephalon. This is in accord with the observation of Webster and Hughes (1999) of an abaxial and anterior splaying of the genal regions which should result in a more semicircular cephalic outline, and compaction related variation of the transverse width of the posterior of the cephalon. Other features expected to vary according to these studies are the ocular length and the glabellar width. The length (sag.) of the preglabellar field was considered to be less prone to deformational effects; nevertheless, this metric varies strongly in the present material. In the majority of the specimens, the preglabellar field has roughly twice the length (sag.) of the anterior border, but it may be only equal in length, or up to three times of the border length. This variation may to some extent be an ontogenetic effect, as there is a tendency for larger specimens to have a shorter preglabellar field. Another feature that shows variation is the relative sagittal position of the genal angle, intergenal swelling and posterior border of LO. The genal angle is roughly opposite to the junction of the axial furrow and posterior cephalic margin, but it may be slightly advanced to the anterior (Fig. $5 \mathrm{~A})$. There is slight variation in the position of the posterior tip of the ocular lobe with regard to SO. In mature cephala, it may vary from directly posterior to where SO meets the axial furrow to about one third of the length (sag.) of LO to the posterior. The three characters are not congruent, such that there are, for example, specimens with a very short preglabellar field, slightly advanced genal angle and the ocular lobes terminating level with SO. Others with very short preglabellar field have the genal angles slightly posterior to the posterior end of the axial furrow and the posterior tips of the occipital lobe some way posterior to SO (Figs 4B, C), to mention only two of the possible combinations occurring. Hence, this variation is considered to be a combination of taphonomic distortion and true biological variation. 

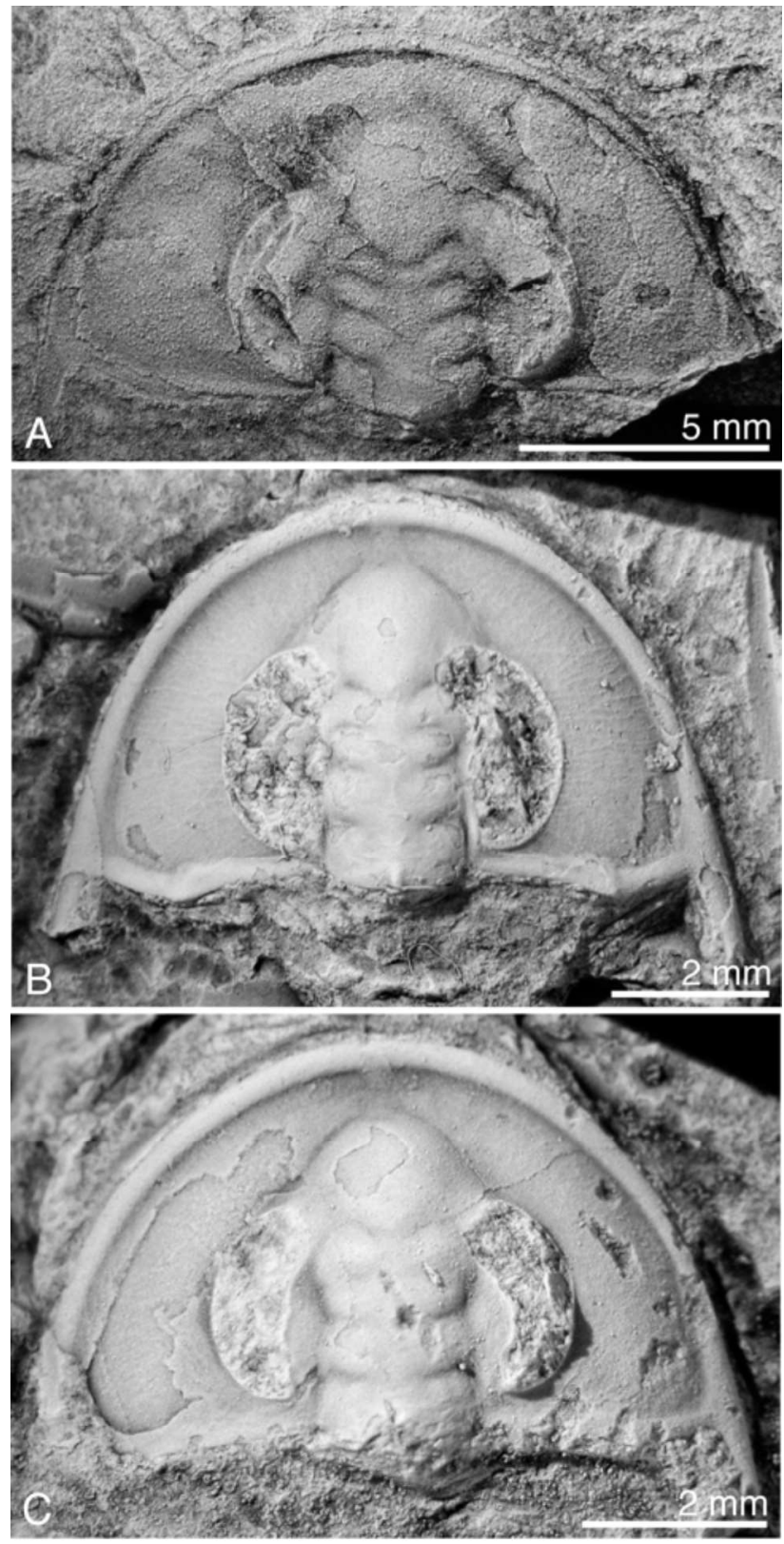

Figure 8. Fritzolenellus lapworthi (Peach and Horne, 1892). A. GSE 13301 from Loch Awe quarry, near Inchnadamph, Scotland; B. Olenellus cf. hanseni (Poulsen, 1932), NMW 97.56G.555, Ella Island Formation, Albert Heim Bjerge; C. Olenellus cf. hanseni (Poulsen, 1932) NMW 97.56G.556, Ella Island Formation, Albert Heim Bjerge.

Types. Lectotype GSE 5364, designated by Cowie and McNamara (1978). Paralectotypes GSE 458, GSE 457, GSE 5366. All stored in the collections of the British Geological Survey, Keyworth, Nottingham, UK.

Occurrence. In north-west Scotland, Fritzolenellus lapworthi occurs in the 'Fucoid' Beds, referred to the socalled Olenellus-Zone (Cambrian Stage 4) by Cowie and McNamara (1978). In North-East Greenland, the species occurs in the Upper Bastion Formation at Albert Heim Bjerge.

Discussion. Fritzolenellus lapworthi was originally described from Allt nan Righreon, Dundonnell, Scotland on the basis of limited material (Peach and Horne, 1892). Subsequent collections from additional localities (Peach, 1894) resulted in a first revision of the species and description of additional taxa including the similar Fritzolenellus reticulatus (Peach, 1894). The latest comprehensive revision of Fritzolenellus lapworth $i$ was provided by Cowie and $\mathrm{McNa}$ mara (1978), chiefly based on new material collected from various localities in Scotland. That study included an investigation of the type material and designation of a lectotype (GSE 5364). It is proposed herein to remove specimen GSE 456 (Peach and Horne 1892, plate 5.5) from the list of paralectotypes. This fragmentary cephalon has a strongly inflated frontal lobe that extends laterally well beyond the merging site of LA and ocular lobe, reminiscent of Wanneria. Paralectotypes GSE 457, 458, 5366 are poorly preserved. Discrimination of Fritzolenellus lapworthi from F. reticulatus can be complicated when the material at hand is poorly preserved.

Cowie and McNamara (1978) compared Fritzolenellus lapworthi to O. hanseni (Poulsen, 1932) from the Ella Island Formation of North-East Greenland. The latter species was based on immature cephala and thoracic fragments. A latex replica of the holotype was available to this study. O. hanseni differs in the presence of a plectrum and the absence of the parafrontal band. Synonymy with F. lapworthi can not be confirmed at present, but material similar to $O$. hanseni is present in the collections of Cowie and Adams from the Ella Island Formation on Ella $\varnothing$ and Albert Heim Bjerge (Fig. 8B, C). Further, material described as Olenellus cf. truemani Walcott, 1913 from the Henson Gletscher and Kap Troedsson formations of North Greenland by Blaker and Peel (1997) shows similarities to $O$. hanseni. The most obvious difference is the presence of a prominent parafrontal band in the material from North Greenland. A revision of O. hanseni may be promising for biostratigraphic correlation of North-East and North Greenland, but is beyond the scope of this paper.

Elsewhere in Greenland, faunas from the lower part of the Cambrian have been described by Christian Poulsen from the Wulff River and Cape Kent formations in Inglefield Land, North-West Greenland (Poulsen, 1958). Several olenellid species, often based on single fragmentary specimens, were described but the material is too poorly preserved to allow comparison. 


\section{Acknowledgments}

I am indebted to J.S. Peel, Uppsala who provided the material and technical discussions, and helped improve the manuscript. J. Bergström, Stockholm, and $\mathrm{M}$. Webster, Chicago, read earlier versions of the manuscript and contributed with valuable discussions. J.O.R. Ebbestad, Uppsala, gave technical advice for the preparation of photographs. M.T. Dean, Edinburgh, facilitated access to the Scottish material. Critical reviews by B.S. Lieberman, Lawrence, and E.N.K. Clarkson, Edinburgh, significantly improved the quality of this paper.

\section{References}

Blaker, M.R. \& Peel, J.S. 1997: Lower Cambrian trilobites from North Greenland. Meddelelser om Grønland, 35:1-145.

Cowie, J.W. \& Adams, P.J. 1957: The geology of the CambroOrdovician rocks of central east Greenland. Part 1: stratigraphy and structure. Meddelelser om Grønland, 153(1):1193.

Cowie, J.W. \& McNamara, K.J. 1978: Olenellus (Trilobita) from the Lower Cambrian strata of North-West Scotland. Palaeontology, 21(3):615-634.

Hall, J. 1861: Supplementary note to the thirteenth report of the Regents of the State Cabinet, p. 113-119. In 15th Annual Report of the New York State Cabinet for Natural History. Albany, New York.

Lake, P. 1937: A monograph of the British Cambrian trilobites. Part X. Palaeontographical Society, London, Monograph, p. 225-248.
Lieberman, B.S. 1998: Cladistic analysis of the Early Cambrian olenelloid trilobites. Journal of Paleontology, 72(1):5978 .

Lieberman, B.S. 1999: Systematic revision of the Olenelloidea (Trilobita, Cambrian). Bulletin of the Peabody Museum of Natural History Yale University, 45:1-150.

Palmer, A.R. 1957: Ontogenetic development of two olenellid trilobites. Journal of Paleontology, 31(1):105-128.

Palmer, A.R. 1998: Terminal Early Cambrian extinction of the Olenellina: Documentation from the Pioche Formation, Nevada. Journal of Paleontology, 72(4):650-672.

Peach, B.N. 1894: Additions to the fauna of the Olenellus-zone of the North-West Highlands. Quarterly Journal of the geological Society of London, 50:661-675.

Peach, B.N. \& Horne, J. 1892: The Olenellus Zone in the NorthWest Highlands of Scotland. Quarterly Journal of the geological Society of London, 48:227-242.

Poulsen, C. 1932: The Lower Cambrian faunas of East Greenland. Meddelelser om Grønland, 87(6):1-66.

Poulsen, C. 1958: Contribution to the palaeontology of the Lower Cambrian Wulff River Formation. Meddelelser om Grønland, 162(2):1-42.

Skovsted, C.B. 2006: Small shelly fauna from the upper Lower Cambrian Bastion and Ella Island Formations, North-East Greenland. Journal of Paleontology, 80(6):1087-1112.

Walcott, C.D. 1910: Cambrian geology and paleontology, no. 6: Olenellus and other genera of the Mesonacidae. Smithsonian Miscellaneous Collections, 5(6):231-422.

Walcott, C.D. 1913: Cambrian geology and paleontology, no. 11: New Lower Cambrian subfauna. Smithsonian Miscellaneous Collections, 57(11):309-326.

Webster, M. \& Hughes, N.C. 1999: Compaction-related deformation in Cambrian olenelloid trilobites and its implications for fossil morphometry. Journal of Paleontology, 73(2):355371 . 